\title{
Hidradenitis Suppurativa: A Systematic Review Integrating Inflammatory Pathways Into a Cohesive Pathogenic Model
}

\author{
Allard R. J. V. Vossen, Hessel H. van der Zee and Errol P. Prens* \\ Department of Dermatology, Erasmus University Medical Center, Rotterdam, Netherlands
}

Background: The pathogenesis of hidradenitis suppurativa (HS) is not fully understood. This systematic review examined the latest evidence for molecular inflammatory pathways involved in HS as a chronic inflammatory skin disease.

Methods: A systematic literature search was performed in PubMed/Medline and EMBASE from January 2013 through September 2017, according to the preferred reporting items for systematic reviews and meta-analyses (PRISMA). Findings on HS

OPEN ACCESS

Edited by:

Angelo Valerio Marzano,

University of Milan, Italy

Reviewed by:

Simone Garcovich

Università Cattolica del Sacro Cuore,

Italy

Sophie Anne Georgin-Lavialle

Université Pierre et Marie Curie,

France

*Correspondence:

Errol P. Prens

e.prens@erasmusmc.nl

Specialty section:

This article was submitted to Autoimmune and Autoinflammatory

Disorders,

a section of the journal

Frontiers in Immunology

Received: 28 September 2018

Accepted: 03 December 2018

Published: 14 December 2018

Citation:

Vossen ARJV, van der Zee HH and

Prens EP (2018) Hidradenitis Suppurativa: A Systematic Review Integrating Inflammatory Pathways Into a Cohesive Pathogenic Model.

Front. Immunol. 9:2965.

doi: 10.3389/fimmu.2018.02965 pathogenesis were also compared with those of other immune-mediated inflammatory diseases (IMIDs) in a non-systematic review. In addition, current therapeutic options for HS are briefly discussed on the basis of the findings for the inflammatory pathways involved in HS.

Results: A total of 32 eligible publications were identified by the systematic search; these were supplemented with three additional publications. The extracted data indicated that four key themes underlie the pathogenesis of HS and related syndromic conditions. First, nicastrin (NCSTN) and PSTPIP1 mutations are directly associated with auto-inflammatory disease. Secondly, the up-regulation of several cytokines including tumor necrosis factor- $\alpha$ and Thelper-17/interleukin-23 are connected to auto-inflammatory mechanisms in the pathogenesis of HS. Thirdly, the microbiome of lesional skin differs significantly vs. normal-appearing skin. Fourthly, HS risk is enhanced through physiological and environmental factors such as smoking, obesity, and mechanical friction. There is significant overlap between the pathogenesis of HS, its syndromic forms and other IMIDs, particularly with respect to aberrations in the innate immune response.

Conclusions: The evidence presented in this review supports $H S$ as an auto-inflammatory skin disorder associated with alterations in the innate immune system. Based on these most recent data, an integrative viewpoint is presented on the pathogenesis of HS. Current management strategies on HS consist of anti-inflammatory therapies, surgical removal of chronic lesions, and lifestyle changes such as smoking cessation and weight loss. As large gaps remain in the understanding of the pathogenesis of HS, further research is warranted to ultimately improve the management and treatment of patients with HS and related syndromic conditions.

Keywords: acne inversa, pyoderma gangrenosum and acne, immune-mediated inflammatory disease, inflammatory bowel disease, auto-inflammation, nicastrin, PSTPIP1, obesity 


\section{INTRODUCTION}

Hidradenitis suppurativa (HS) is a chronic, recurrent, inflammatory follicular occlusive disease, that usually presents after puberty with painful, inflamed lesions, predominantly at inverse body sites such as the axillae, inguinal and anogenital regions (1). The physiological and psychological consequences of HS can profoundly reduce a patient's quality of life $(1,2)$. Prevalence estimates in North America and Europe range from $<1$ to $4 \%(3,4)$.

The pathogenesis of HS is not fully understood. Current evidence highlights a complex multifactorial pathogenesis (5). A key triggering factor is the occlusion of the hair follicle, caused by keratosis and hyperplasia of the follicular epithelium leading to cyst development $(6,7)$. Subsequently, the cyst will rupture, causing a fierce immune response and inflammation that, depending on the severity, may progress to abscess and sinus tract development and scarring $(6,7)$. The name of the disease implies that sweating and bacterial infection are a fundamental part of the disease process. This is misleading and now considered a misnomer: no evidence has been found showing that HS is triggered by events in the apocrine or eccrine glands. Environmental risk factors reported to contribute to HS development include smoking and obesity (8). In addition, HS can occur with several co-morbid immunemediated inflammatory diseases (IMIDs), notably inflammatory bowel disease (IBD) (9).

Clear evidence suggests the involvement of pro-inflammatory cytokines in immune dysregulation in HS, with elevated levels of tumor necrosis factor (TNF)- $\alpha$, interleukin (IL)-1ß, IL-17 and interferon (IFN) $-\gamma$ observed in HS lesions $(5,10,11)$. Data also indicate the involvement of Thelper (Th) cells, which accumulate in HS lesions, in the pathogenesis of HS $(11,12)$. In addition, studies have shown that antimicrobial peptides (AMPs) like cathelicidin (LL-37) and human $\beta$-defensin are increased in HS lesions compared with normal skin of HS patients (13). The use of TNF- $\alpha$ inhibitors such as adalimumab and infliximab have been associated with improvements in immune dysregulation in HS and support the importance of local molecular drivers in the pathogenesis of HS $(1,14,15)$.

Furthermore, mutations in $\gamma$-secretase genes, whose gene products act on many substrates including Notch (16), suggest that Notch or other substrates of $\gamma$-secretase may play a role in the pathogenesis of HS. Interestingly, $\gamma$-secretase knock-out mice are characterized by a phenotype of multiple cutaneous cysts, a key feature of HS (17). To date it remains unclear whether the effects of Notch on follicle development or its immune role play a significant role in HS pathogenesis.

Rapidly evolving understanding in the auto-inflammatory arena is needed to improve awareness of HS, disease management, and ultimately improve patient outcomes. The aim of this systematic literature review was to summarize recent findings on the pathogenesis of $\mathrm{HS}$ and its syndromic forms, and to identify common pathways involved in HS pathogenesis and other IMIDs. Ultimately, we integrate the molecular pathways into a cohesive pathogenic model.

\section{METHODS}

A systematic review of recent original research was conducted according to the Preferred Reporting Items for Systematic review and Meta-Analyses Protocols (PRISMA-P) 2009 statement to identify the factors involved in the pathogenesis of HS (18).

A two-stage review process of PubMed/Medline and EMBASE databases was conducted using search strings designed to recognize studies reporting on auto-inflammatory disorders within the scope of HS (see Supplementary Tables 1,2). The initial screening review identified studies published in English language from January 2007 through September 2017. After removing duplicate records, two reviewers independently screened the titles and abstracts in a double-blind manner and excluded those that did not meet the screening review inclusion criteria (Supplementary Table 3). Results were reviewed by a senior analyst for authentication and resolution of disagreements between the reviewers. Identified publications were reassessed according to the full-text review inclusion criteria; at this stage, the publication period was narrowed to January 2013 through September 2017 on the basis of the number of publications identified during screening; this was to ensure focus on the most recent data (Supplementary Table 3). Two reviewers, overseen by a senior analyst, independently assessed the remaining full-text copies of all relevant publications and any duplicate, low-quality or outdated publications were excluded. The bibliographies for all publications selected in the full-text review were also manually checked for relevant references.

Data were extracted from each relevant publication on study design (study setting, data source, study period), patient characteristics (sample size, mean age, sex, HS severity, disease location, notable comorbidities, smoking status), immunogenetic factors (genes, mutations or proteins involved), environmental factors (microbiological pathways, obesity, smoking, mechanical stress, sex, hormones), inflammatory pathway and cytokine status (pro-inflammatory, anti-inflammatory, proliferation, and growth factors).

In addition to the systematic review process, two informal literature searches were performed using the same databases, to facilitate discussion of the data. First, immunogenetic factors of HS are compared with other IMIDs such as Crohn's disease (CD), ulcerative colitis (UC), ankylosing spondylitis (AS), psoriasis and psoriatic arthritis (PsA), pyoderma gangrenosum (PG), and Behçet's disease. Second, actual therapeutic options for HS are briefly discussed on the basis of the inflammatory pathways involved in the pathogenesis of HS.

\section{RESULTS}

The initial search in PubMed and EMBASE identified a total of 3,580 records. Of these, 230 publications were screened for full-text review and 32 publications were selected for data extraction (Figure 1). Data from an additional three publications were also reviewed as they were considered to provide relevant information; two had been excluded during the systematic search 


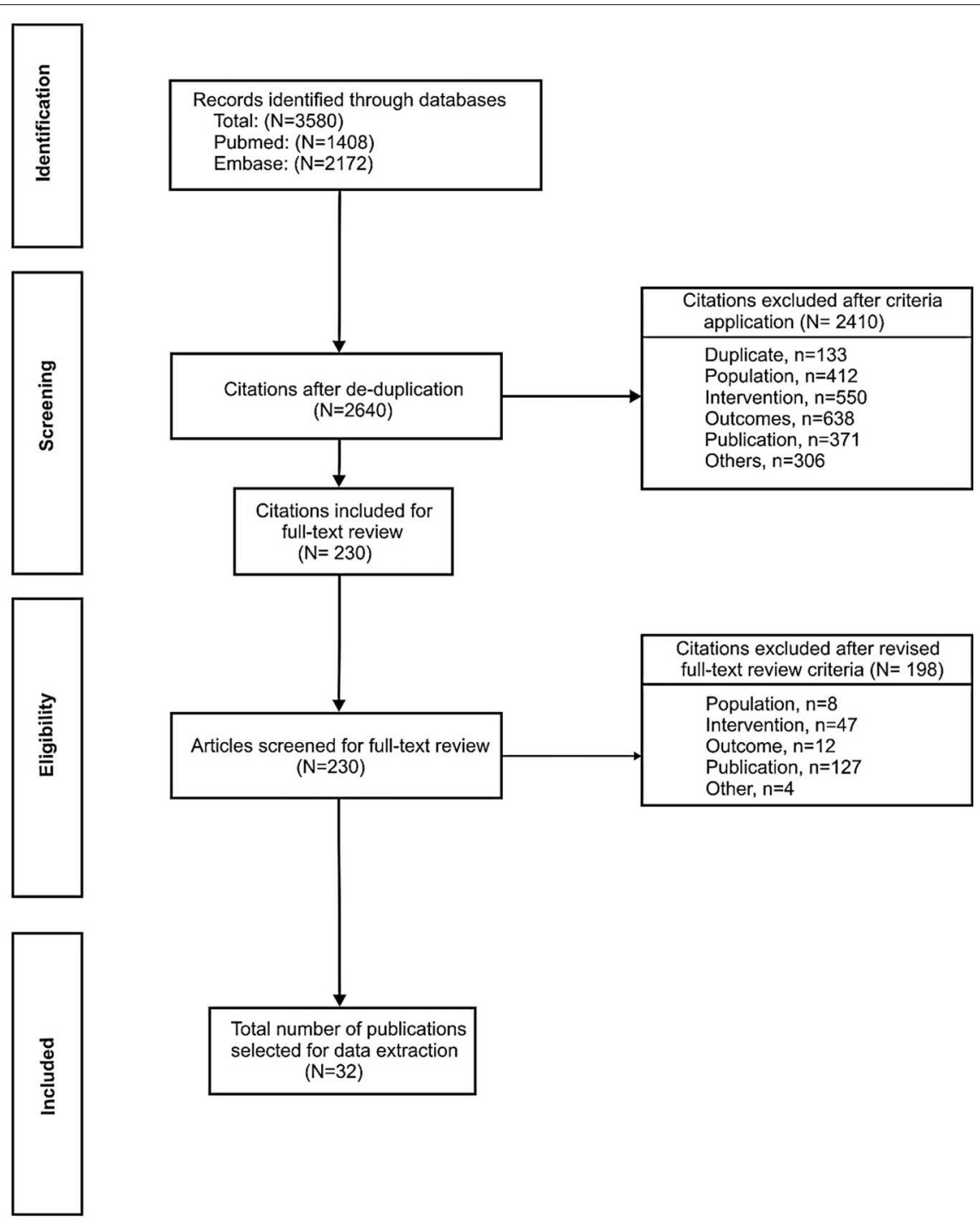

FIGURE 1 | PRISMA flow diagram of included studies. To supplement the 32 publications identified through the systematic process, data from three additional publications were also reviewed as they were considered to provide relevant information; two had been excluded during the systematic search on the basis of their publication type (editorial/letter) $(19,20)$ and one was published subsequently to the search end date (21).

on the basis of their publication type (editorial/letter) $(19,20)$ and one was published subsequently to the search end date (21).

The data extracted from these 35 publications were largely derived from four main lines of investigation in patients with HS and its syndromic forms: (1) genetic analyses (covered by 16 studies); (2) inflammatory marker levels (12 studies); (3) microbe analyses in lesions/expression of antimicrobial peptides (6 studies); and (4) contribution of physiological and environmental risk factors (11 studies) (Table $\mathbf{1})$.

\section{Genetics}

\section{Loss of Function Mutations in $\gamma$-Secretase Complex Genes}

Three studies identified by our review evaluated NCSTN gene mutations for the nicastrin protein subunit of $\gamma$-secretase in connection with HS pathogenesis $(25,26,31)$. Genetic analyses in Chinese and Japanese families identified mutations in the NCSTN gene (c.647A > C, c.223G $>$ A and c.582+1delG) carried by affected family members but not unaffected family members or healthy controls $(25,26)$. Meanwhile, an in vitro study in familial HS identified that mutations in NCSTN affect downstream signaling through Notch and/or phosphoinositide 3-kinase (PI3K) (31). However, NCSTN mutations in HS did not enhance cytokine production in LPS-stimulated peripheral blood mononuclear cells (20).

\section{Mutations of Proline-Serine-Threonine Phosphatase Interacting Protein 1}

Proline-serine-threonine phosphatase interacting protein 1 (PSTPIP1) is a cytoskeleton-associated adaptor protein, highly expressed in hemopoietic cells (29). The protein manifests its immunomodulatory effects through downregulation of CD2 
TABLE 1 | Characteristics of included studies.

\begin{tabular}{|c|c|c|c|c|c|}
\hline \multirow{2}{*}{$\begin{array}{l}\text { Factors associated } \\
\text { with HS }\end{array}$} & \multicolumn{2}{|r|}{ Studies } & \multirow{2}{*}{$\begin{array}{l}\text { Patients } \\
\text { Per condition (n) }\end{array}$} & \multirow[t]{2}{*}{ Study location (n) } & \multirow[t]{2}{*}{ References } \\
\hline & Total, $\mathbf{n}$ & Per condition (n) & & & \\
\hline Genetics & 16 & $\begin{array}{l}\mathrm{HS} / \mathrm{Al}(8) \\
\mathrm{PG}(2) \\
\text { PAPA (2) } \\
\text { PAC (1) } \\
\text { PASH (2) } \\
\text { PAPASH (1) } \\
\text { SAPHO, RA, AS, SPA (1) }\end{array}$ & $\begin{array}{l}\mathrm{HS} / \mathrm{Al}(368) \\
\text { PG (15) } \\
\text { PAPA/PAPA-like }(\sim 12)^{\alpha} \\
\text { PAC (1) } \\
\text { PASH (8) } \\
\text { PAPASH (1) } \\
\text { SAPHO (71), RA (125), AS } \\
\text { (67), SPA (35) }\end{array}$ & $\begin{array}{l}\text { Europe (7) } \\
\text { Asia (5) } \\
\text { Middle East (2) } \\
\text { North America (2) }\end{array}$ & $(3,19,20,22-34)$ \\
\hline Inflammatory markers & 12 & $\begin{array}{l}\mathrm{HS} / \mathrm{Al}(10) \\
\mathrm{PG}(2) \\
\mathrm{PASH}(1)\end{array}$ & $\begin{array}{l}\mathrm{HS} / \mathrm{Al}(351) \\
\mathrm{PG}(15) \\
\mathrm{PASH}(7)\end{array}$ & $\begin{array}{l}\text { Europe (9) } \\
\text { North America (2) } \\
\text { Asia (1) }\end{array}$ & $(5,28,31,33,35-42)$ \\
\hline Microbiome & 6 & $\mathrm{HS} / \mathrm{Al}(6)$ & HS (297) & Europe (6) & $(43-48)$ \\
\hline $\begin{array}{l}\text { Physiological and } \\
\text { environmental risk }\end{array}$ & 11 & $\mathrm{HS} / \mathrm{Al}(11)$ & HS (738) & $\begin{array}{l}\text { Europe (10) } \\
\text { Asia (1) }\end{array}$ & $(21,26,43,45-52)$ \\
\hline
\end{tabular}

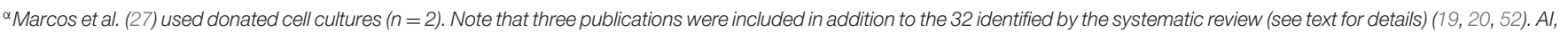

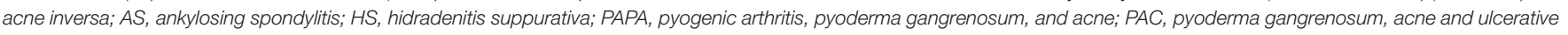

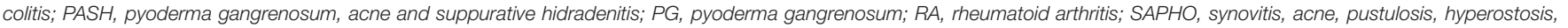
and osteitis; SPA, seronegative spondyloarthropathy.

(-triggered adhesion, regulation of c-Abl tyrosine kinase activity, and interaction with other immunity-related proteins including the Wiskott-Aldrich syndrome protein (WASp) (28) and pyrin, the familial Mediterranean fever (FMF) protein (29).

There is now evidence of mutations to the PSTPIP1 gene in cases of pyoderma gangrenosum, acne and suppurative hidradenitis (PASH) and pyogenic arthritis, pyoderma gangrenosum, acne and suppurative hidradenitis (PAPASH) syndromes $(19,24)$. A p.E277D missense mutation was detected in the PASH case (24), whilst the patient with PAPASH had a heterozygous missense mutation (c.1213 C>T [p.Arg405Cys]) in exon 15 of PSTPIP1. Variations have also been reported in the PSTPIP1 gene in other related syndromic conditions $(22,28,29)$. First, a genetic analysis in a patient with a PAPA-like syndrome revealed a recessive inheritance pattern with a homozygous PSTPIP1 mutation (c.773G $>$ C and p.Gly258Ala), in contrast to a previously reported heterozygous polymorphism (22). Secondly, a patient with aggressive PG was found to have a novel PSTPIP1R405C mutation (28). Data from this case study indicated that endogenous PSTPIP1 negatively regulates macrophage podosome formation and extracellular matrix degradation. Thirdly, a novel mutation in the PSTPIP1 gene resulted in a case of pyoderma gangrenosum, acne and ulcerative colitis (PAC). The associated elevated IL-1 $\beta$ levels were responsive to the IL-1R antagonist anakinra (29). It is worth noting, however, that findings from a biochemical study suggested that PSTPIP1 mutations associated with PAPA syndrome do not alter the negative regulatory role of PSTPIP1 in T-cell activation (27).

\section{Other Genes Implicated in HS}

In a study of 139 unrelated patients with HS, single nucleotide polymorphisms of the $I L-12 R b 1$ gene coding for the IL$12 \mathrm{Rb} 1$ receptor subunit did not genetically predispose to HS
(23). However, their carriage was directly associated with the phenotype of HS, indicating the importance of the IL-12/IL23 pathway for the pathogenesis of HS. Findings from a casecontrol study of two independent and genetically diverse cohorts of patients with HS from Greece $(n=163)$ and Germany $(n=98)$ suggested that the copy number of the $\beta$-defensin gene cluster (DEFB) both confers susceptibility for HS and modulates the disease phenotype (30).

In a study involving 298 Han Chinese patients with a range of auto-inflammatory diseases (Synovitis, Acne, Pustulosis, Hyperostosis and Osteitis [SAPHO], rheumatoid arthritis, AS and seronegative spondyloarthropathy), an AS-associated single-nucleotide polymorphism (rs6908425 in CDKAL1) was associated with the risk of developing SAPHO syndrome (32).

A genetic analysis of auto-inflammation in PG (13 patients) and the syndromic form PASH (7 patients) identified mutations in a range of auto-inflammatory genes (MEFV, NLRP3, NLRP12, NOD2, LPIN2, and PSTPIP1), suggesting the involvement of inflammatory pathways such as NLRP inflammasomes, cystolic pattern recognition sensors, the innate immune system, and IL-1 $\beta$ signaling (33).

In addition to the genetic analyses, two biochemical studies implicated other proteins in the pathogenesis of HS. Microarray data from one study suggested altered sphingolipid metabolism in HS skin lesions compared with normal skin (3).

In a study of surgically excised skin or skin punch biopsies, HS skin lesions showed on average 25-fold higher lipocalin 2 (LCN2) mRNA expression levels compared with the skin of healthy donors (34).

\section{Inflammatory Markers}

There is increasing interest regarding the role markers of inflammation in patients with HS or other syndromic forms. A study in 14 patients with HS reported TNF- $\alpha$-positive 
inflammatory cells in the dermis of patients but not in healthy controls (35). A study comparing the presence of different inflammatory cytokines in wound fluid specimens demonstrated elevated levels of IFN- $\gamma$ and TNF- $\beta$ in HS lesions compared with samples from age-matched chronic wound patients (5).

A retrospective study of HS outpatient medical files found a significant association between C-reactive protein (CRP) levels and neutrophil count with HS disease severity (36). A second study reported elevated serum CRP levels in patients with HS compared with healthy volunteers (38). A number of studies have reported elevated mRNA and/or protein levels of interleukins in the skin or serum. Alterations in the skin have been reported for IL-1 $\beta$ (33), CXCL-8/IL-8 (33, 37), IL-17/IL-17A (33), IL-32 (42), and IL-36/IL-36 $\alpha / \mathrm{IL}-36 \beta / \mathrm{IL}-36 \gamma(37,41)$. Alterations in the serum have been reported for IL-1 $\beta$ (38), IL-6 (38), CXCL-8/IL-8 (38), IL-10 (38), IL-12p70 (38), and IL-17/IL-17A $(38,39)$.

Keratinocytes isolated from non-lesional skin of patients with HS exhibited a pro-inflammatory profile in addition to an enhanced production of AMPs such as hBD-2, psoriasin (S100A7), and calgranulin (S100A8) (44), indicating that the skin immune system is already activated in the steady state.

\section{Microbiome}

A number of studies investigated bacterial cultures from HS lesions and generated evidence implicating the involvement of microbes in disease pathogenesis. A histologic study of 42 patients with chronic HS identified bacterial aggregates (biofilms) in $67 \%$ of chronic lesion samples and in $75 \%$ of perilesional samples (47). The same author group conducted a case-control study of punch biopsy specimens and demonstrated that the microbiome in patients with HS differs significantly from that in healthy controls in both lesional and non-lesional skin (48). A microbial analysis of lesional vs. unaffected skin from 65 patients with HS identified anaerobic microbes in $83 \%$ lesions vs. $53 \%$ control samples, and the microbiome varied with disease severity (45). These bacteria were associated with low pathogenicity. An extensive prospective microbiological study identified two opportunistic bacterial pathogens associated with HS lesions (S. lugdunensis and anaerobic actinomycetes) (43). These pathogens can cause abscesses and severe infections. A cross-sectional study of 50 patients reported that bacterial colonization was correlated with severity and localization of HS lesions (46). Over two-thirds (68.8\%) of patients with both aerobic and anaerobic bacteria had the most severe grade of HS (Hurley stage III).

\section{Physiological and Environmental Risk Factors}

Findings from the literature review supported the involvement of previously suggested physiological and environmental risk factors, such as smoking and obesity, in HS (36, 49, 51). A postal follow-up survey study $(n=212)$ found the chance of remission from HS may be improved in non-smokers vs. smokers, and in non-obese (body mass index [BMI] <30) vs. obese patients (49). In contrast, a retrospective study of inflammatory serum markers in HS outpatients found no association between smoking status and HS severity but smoking was associated with increased neutrophil counts (36). This study did find an association between increased BMI and HS severity, whereas there was no correlation between BMI and neutrophil counts.

Related to obesity, an analysis of 14 obese patients with HS described the role of mechanical stress (for example on the abdomen at the level of the waistband) in promoting the "Koebner phenomenon" in HS (51). The development of lesions at sites of traumatized but previously uninvolved skin highlights the importance of localized environmental factors in HS development. A hospital-based cross-sectional study conducted in the Netherlands reported a significantly higher average BMI in 106 patients with HS vs. 212 general dermatological patients (21). Among those patients identified as obese, bodyweight distribution was more peripheral in patients with HS than those without, consistent with enhanced friction due to overlapping skin folds.

Kromann and colleagues reported no clear effect of pregnancy or menopause on HS symptoms (49). However, in a crosssectional survey based study, a substantial subset of women did experience HS-related alterations, with deterioration of HS around menses and amelioration of symptoms during pregnancy reported in $43 \%(n=80)$ and $30 \%(n=29)$ of the respondents, respectively (52).

\section{Evidence for Shared Pathology With Other IMIDs}

To consider the above findings in relation to the pathogenesis of other established IMIDs, an informal literature review was conducted. Inflammatory bowel disease (CD and UC), AS, psoriasis, PsA, PG and Behçet's disease are characterized by different pathogeneses but they also share common immunological, genetic and risk factors (Table 2).

Several cytokines are systemically-raised in many of these IMIDs, particularly those implicated in the Th1 and Th17 responses, including TNF- $\alpha$, IL-12/23, IL-17, IL-12, IFN- $\gamma$, IL$1 \beta$, and the IL-1 family including IL-36 $(33,37,60,67,73)$. Several of the inflammatory cytokines have also been shown to be upregulated in HS [e.g., IFN- $\gamma(5)$, IL-2, TNF- $\alpha(33,35)$ and TNF$\beta$ (5)] are produced by Th1 cells, implicating the Th1 response in the pathogenesis of HS. Furthermore, the IL-36 family, also found to be upregulated in HS $(37,41)$, plays an important role in the modulation of Th1 and Th17 immune responses.

Data also support the notion of shared genetic pathways of inflammation. For example, NOD2 mutations in $\mathrm{CD}$ are identified in PG and PASH (33) but conflicting evidence concerns their association with psoriasis and PsA $(63,75)$. MEFV mutations are found in FMF as well as PG and PASH; co-occurrence of FMF and HS is not uncommon $(33,76)$. Other genes conferring susceptibility in CD, such as OCTN, are associated with PsA (63).

In addition to shared genetic factors, the overlap in risk factors observed for different IMIDs also highlights the similar mechanisms that account for them. For example, smoking may confer a protective role in the pathogenesis of UC, PG and Behçet's disease but increases susceptibility in $\mathrm{CD}, \mathrm{AK}$, psoriasis 
TABLE 2 | Pathogenesis of established immune mediated inflammatory diseases in relation to hidradenitis suppurativa.

\begin{tabular}{|c|c|c|c|c|c|c|}
\hline Disease & Disease overview & $\mathrm{Key}^{\alpha}$ genetic factor(s) & $\begin{array}{l}\text { Key }^{\alpha} \text { cytokine } \\
\text { profile }\end{array}$ & Biologics & Risk factors & References \\
\hline HS & $\begin{array}{l}\text { Inflammatory skin disease } \\
\text { with genetic, immunological, } \\
\text { and environmental } \\
\text { background }\end{array}$ & $\begin{array}{l}\gamma \text {-secretase (NCSTN), } \\
\text { PSTPIP1 }\end{array}$ & $\begin{array}{l}\text { Th1, Th17 } \\
\text { IL-1 } 1 \beta, 6, \\
\text { CXCL/IL-8,12, 17, } \\
\text { 23, IFN- } \gamma, \text { TNF- } \alpha\end{array}$ & $\begin{array}{l}\text { Anti-TNF- } \alpha \\
\text { inhibitors }\end{array}$ & $\begin{array}{l}\text { Smoking, obesity, } \\
\text { mechanical friction }\end{array}$ & $\begin{array}{l}(5,19,24- \\
26,31,33,36- \\
38,41,49,51)\end{array}$ \\
\hline \multicolumn{7}{|l|}{ IBD } \\
\hline CD & $\begin{array}{l}\text { Imbalance between gut } \\
\text { microbiome and host } \\
\text { immune system with genetic } \\
\text { background }\end{array}$ & $\begin{array}{l}\text { NOD2 (CARD15), ATG16L1, } \\
\text { IRGM, FUT2, OCTN, } \\
\text { TNFSF15, IL10, IL12B, } \\
\text { IL23R, HLA, STAT3, JAK2, } \\
\text { TNFSF15, MUC1 }\end{array}$ & $\begin{array}{l}\text { Th1, Th17 IL-1 } \\
6,12,17,23 \\
\text { IFN- } \gamma, \text { TNF- } \alpha\end{array}$ & $\begin{array}{l}\text { Anti-TNF- } \alpha \\
\text { inhibitors }\end{array}$ & $\begin{array}{l}\text { Smoking, diet, vitamin D } \\
\text { deficiency, medications, } \\
\text { enteric infections }\end{array}$ & $(53-55)$ \\
\hline UC & $\begin{array}{l}\text { Imbalance between gut } \\
\text { microbiome and host } \\
\text { immune system with genetic } \\
\text { background }\end{array}$ & $\begin{array}{l}\text { HNF4A, CDH1, LAMB1, } \\
\text { GNA12, SLC9A, TNFSF14, } \\
\text { ECM1, IL10, IL12B, IL23R, } \\
\text { HLA, STAT3, JAK2, } \\
\text { TNFSF15, MUC1 }\end{array}$ & $\begin{array}{l}\text { Th2, Th17 } \\
\text { IL-1 } \beta, 6,12,13 \text {, } \\
17,23 \text { TNF- } \alpha\end{array}$ & $\begin{array}{l}\text { Anti-TNF- } \alpha \\
\text { inhibitors }\end{array}$ & $\begin{array}{l}\text { Non-smoking, } \\
\text { appendectomy, diet, vitamin } \\
\text { D deficiency, medications, } \\
\text { enteric infections }\end{array}$ & (55) \\
\hline AS & $\begin{array}{l}\text { Imbalance between gut } \\
\text { microbiome and host } \\
\text { immune system with genetic } \\
\text { background }\end{array}$ & $\begin{array}{l}\text { HLA-B27, HLA-B40, } \\
\text { ERAP1/2, CARD9, IL12B. } \\
\text { IL23R, IL27, STAT3, JAK2, } \\
\text { TYK2 }\end{array}$ & $\begin{array}{l}\text { Th17 IL-6, 17, 22, } \\
23,26, \text { IFN- } \gamma \\
\text { TNF- } \alpha\end{array}$ & $\begin{array}{l}\text { Anti-TNF- } \alpha \\
\text { inhibitors }\end{array}$ & $\begin{array}{l}\text { Infection, smoking, } \\
\text { testosterone }\end{array}$ & $(56-62)$ \\
\hline Psoriasis & $\begin{array}{l}\text { Inflammatory skin disease } \\
\text { with genetic and } \\
\text { immunological background }\end{array}$ & $\begin{array}{l}\text { PSOR1, HLA-C, ERAP1, } \\
\text { LCE3D, IL12B, IL23R, } \\
\text { TNFAIP3, ZNF313, TYK2, }\end{array}$ & $\begin{array}{l}\text { Th1, Th17 } \\
\text { IL-2, 17, 22, 23, } \\
26, \text { TNF- } \alpha, \text { IFN- } \gamma\end{array}$ & $\begin{array}{l}\text { Anti-TNF- } \alpha \\
\text { inhibitors, T cell } \\
\text { targeted therapies }\end{array}$ & Obesity, infection & $(63-68)$ \\
\hline PsA & $\begin{array}{l}\text { Inflammatory arthritis } \\
\text { associated with psoriasis } \\
\text { with genetic, immunological, } \\
\text { and environmental } \\
\text { background }\end{array}$ & $\begin{array}{l}\text { HLA-B. HLA-C, OCTN } \\
\text { IL12B, IL23R }\end{array}$ & $\begin{array}{l}\text { Th1, Th17 } \\
\text { IL17, 23, TNF- } \alpha\end{array}$ & $\begin{array}{l}\text { Anti-TNF- } \alpha \\
\text { inhibitors }\end{array}$ & $\begin{array}{l}\text { Physical trauma, smoking, } \\
\text { obesity, infection, heredity }\end{array}$ & \\
\hline$P G$ & $\begin{array}{l}\text { Inflammatory, ulcerating, } \\
\text { neutrophilic skin disease } \\
\text { with genetic, immunological, } \\
\text { and environmental } \\
\text { background }\end{array}$ & $\begin{array}{l}\text { MEFV, NLRP3, NLRP12, } \\
\text { NOD2, LPIN2, PSTPIP1 }\end{array}$ & $\mathrm{IL}-1 \beta, 17, \mathrm{TNF}-\alpha$ & $\begin{array}{l}\text { Anti-TNF- } \alpha \\
\text { inhibitors }\end{array}$ & $\begin{array}{l}\text { Physical trauma, } \\
\text { non-smoking, metabolic } \\
\text { syndrome }\end{array}$ & $(33,69-71)$ \\
\hline $\begin{array}{l}\text { Behçet's } \\
\text { disease }\end{array}$ & $\begin{array}{l}\text { Multi-systemic, } \\
\text { inflammatory, vasculitis with } \\
\text { genetic, immunological, and } \\
\text { environmental background }\end{array}$ & $\begin{array}{l}\text { HLA-B5, ERAP1 } \\
\text { IL10, IL12RB2, } \\
\text { IL-23R,STAT4, } \\
\text { CCR1-CCR3, KLRC4, } \\
\text { TNFAIP3, FUT2 }\end{array}$ & $\begin{array}{l}\text { Th1, Th17 IL-6, } \\
\text { 11, 17, 21, 22, 26, } \\
\text { TNF- } \alpha, \\
\text { Chitinase3-like1, } \\
\text { gp130/sIL-6Rb, } \\
\text { sTNF-R1, } \\
\text { sTNF-R2 }\end{array}$ & $\begin{array}{l}\text { Anti-TNF- } \alpha \\
\text { inhibitors, anti-IL1, } \\
\text { INF- } \alpha\end{array}$ & $\begin{array}{l}\text { Non-smoking, obesity, } \\
\text { infection }\end{array}$ & $(69,72-74)$ \\
\hline
\end{tabular}

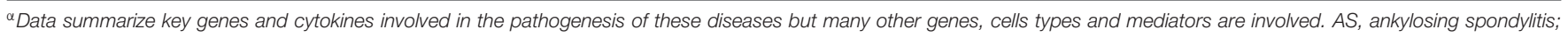
$C D$, Crohn's disease; HS, hidradenitis suppurativa; PG, pyoderma gangrenosum; PsA, psoriasis and psoriatic arthritis; UC, ulcerative colitis.

and PsA (Table 2). With the exception of AK and conflicting evidence for Behçet's disease $(56,74)$, the pathogenesis of most IMIDs appears unrelated to sex-specific factors. Understanding the distinct and shared genetic, immunologic and risk factor profiles of IMIDs will aid the development of effective treatments to target the pathogenic mechanisms involved and modify the disease course.

It has previously been proposed that the link between HS and other conditions with demonstrated systemic pathology may be attributed to common genetic or environmental factors and/or shared inflammatory pathways (77). The data identified in this review demonstrate the significant overlap between the pathogenesis of HS and the aforementioned IMIDs. The most striking similarity among these diseases is that of aberrations in the innate immune response, particularly the IL-23/Th17 pathway (Table 2).

\section{Integrated Viewpoint on HS Pathogenesis "Sequence of Events"}

By identifying the latest publications on the pathogenesis of HS and evaluating it in the context of more established pathogenic mechanisms for known IMIDs, this review has collated substantial evidence that HS is a chronic immune-mediated auto-inflammatory disease with a multifactorial pathogenesis.

Four key themes have emerged from this review. First, genetic factors play a key role in causing HS. Mutations in a range of genes, including NCSTN mutations in the $\gamma$-secretase complex and PSTPIP1 mutations, are directly associated with auto-inflammatory disease $(26,27,29,31)$. However, the majority of HS cases appear to be non-familial, suggesting the existence of separate subsets and the need for stratification within patients diagnosed with HS (25). Secondly, the up-regulation of cytokines 
including TNF- $\alpha$ and a range of cytokines (predominantly Th17-related) are connected to auto-inflammatory mechanisms in the pathogenesis of $\mathrm{HS}(5,35,38)$. Thirdly, there is an alteration in the local microbiome of normal-appearing vs. lesional skin $(43,45,47,48)$. Data also suggest that bacterial aggregates are associated with inflammation of chronic HS lesions, and it is proposed that they most likely occur as a secondary event, possibly due to predisposing local anatomical changes such as sinus tracts (tunnels), keratinous detritus and dilated hair follicles (47). Finally, enhancement of HS risk occurs via a range of physiological and environmental factors such as smoking, obesity and mechanical friction $(21,36,49$, 51).

On the basis of the evidence reviewed here, we are able to take a cohesive view and to propose a three-stage sequence of events that contribute to the pathogenesis of HS. This integrated viewpoint is illustrated schematically in Figure 2.

The first event is follicular occlusion with subsequent dilation. This may be driven by endogenous factors in individuals harboring a genetic predisposition for an enhanced risk of infundibular keratinisation and cyst formation. Exogenous factors such as smoking, mechanical friction and metabolic
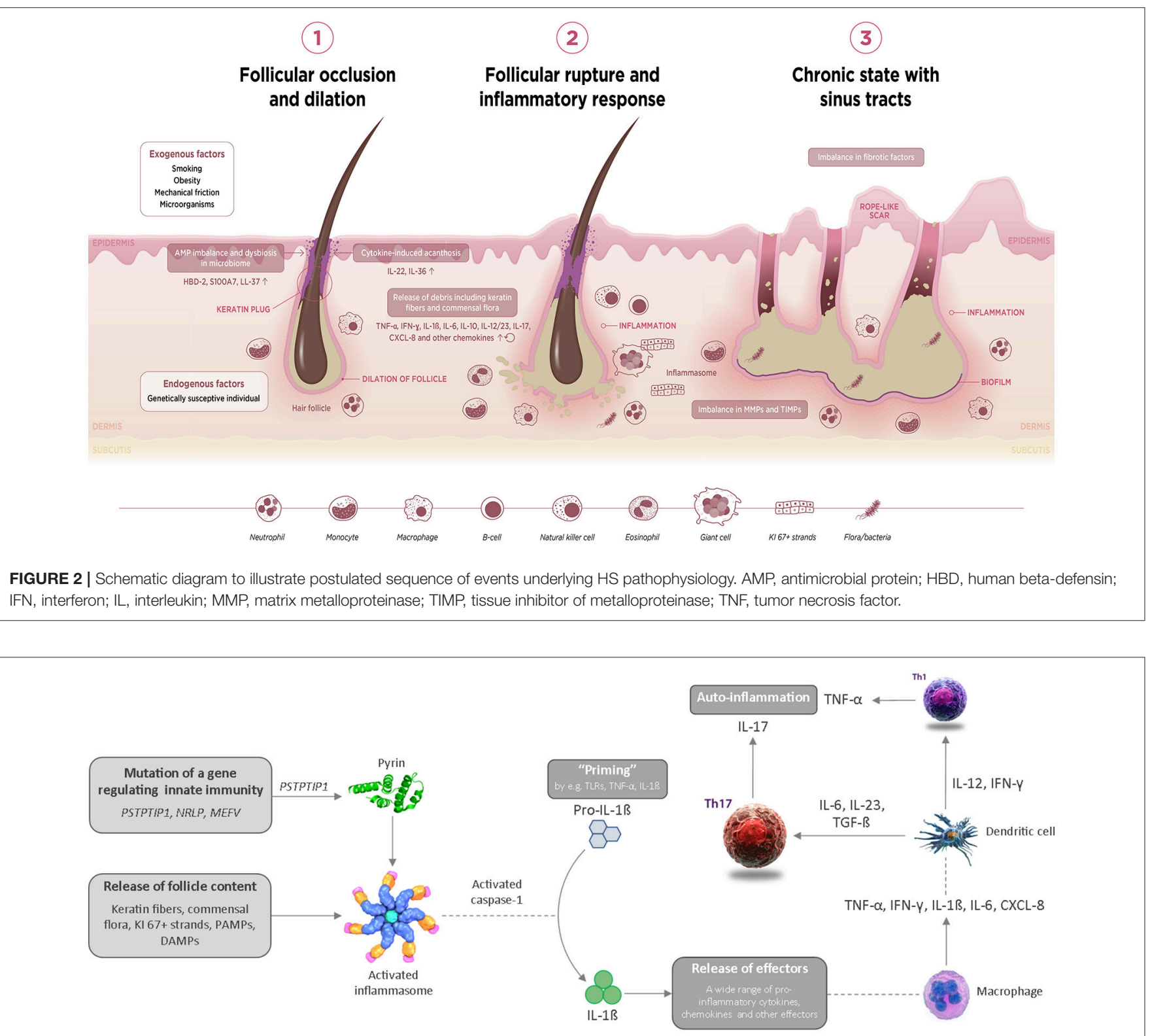

FIGURE 3 | Schematic diagram illustrating activation of the inflammasome in HS and related syndromes, which ultimately results in an auto-inflammatory immune response. CXCL, chemokine ligand; DAMP, danger-associated molecular pattern; IL, interleukin; IFN, interferon; PAMP, pathogen-associated molecular pattern; Th, T helper cell; TLR, toll-like receptor; TNF, tumor necrosis factor. 
changes such as obesity-which is associated with acanthosisalso contribute to occlusion of the follicular isthmus. Furthermore, occlusion of the hair follicle may lead to a dysregulation of the homeostatic keratinocyte symbiosis and microbial dysbiosis, making the skin prone to a Th1/Th17-driven inflammatory disease.

The second event is rupture of the dilated follicle. The scattering of follicle content in the dermis including keratin fibers, commensal flora or pathogen- and damage-associated molecular patterns (PAMPs/DAMPs) triggers an acute and severe immune response. The anatomical location, i.e., the inverse body areas, and enhanced mechanical friction at these predilection sites facilitates the inward rupture and extension of inflammation. We argue that release of the follicular debris into the dermis results in simultaneous activation of multiple inflammatory pathways, particularly Th17/IL-23, the (NLRP) inflammasomes and innate receptors (toll-like receptors, TLRs such as TLR2). Activation of the inflammasome in HS and related syndromes including $\mathrm{PASH}$ and $\mathrm{PAPA}(\mathrm{SH})$ is illustrated schematically in Figure 3. This is accompanied by histological alterations with a diverse cell infiltrate characterized by the mixed participation of monocytes, neutrophils, multinucleated giant cells, B-cells, plasma cells, T-cells, and natural killer cells, leading to an erythematous nodule or fluctuating abscess.

The third event is chronic inflammation with sinus tract or tunnel formation. Following follicular rupture, sequestered proliferating $\mathrm{Ki}-67+$ epithelial strands promote continuous activation of the immune system. The presence of epithelial strands in the dermis, in addition to an imbalance in matrix metalloproteinases (MMPs) and tissue inhibitors of metalloproteinase (TIMPs), and increased activity of fibrotic factors such as tissue growth factor (TGF)- 3 1-2-3, may lead to scarring and the development of sinuses/tunnels or fistulae, a hallmark of chronic HS. These intracutaneous (partly) epithelialized cavities provide an excellent habitat for biofilmproducing bacteria, which are able to continuously trigger inflammation with associated purulent drainage. Furthermore, we hypothesize that circulating pro-inflammatory cytokines and chemokines from chronic lesions may activate the immune system of the hair follicle in distant predilection sites.

\section{Current Therapeutic Options for HS}

HS management usually consists of the combination of both medical therapies and surgical interventions. The main treatment goal, to improve patients' quality of life, can be achieved by reducing the inflammation-related pain and purulent discharge, limiting the incidence and duration of flares, and removing chronic lesions using surgical techniques (78). A short overview of current treatment options including the therapeutic target and/or the suggested pathophysiological link(s) is depicted in Table 3. These data summarize anti-inflammatory therapies in addition to surgery and lifestyle changes such as smoking

TABLE 3 | Short overview of actual treatment options for hidradenitis suppurativa, based on Van Straalen et al. (78).

\begin{tabular}{|c|c|c|}
\hline Treatment options $^{\alpha}$ & Therapeutic target or suggested pathophysiological link & References $^{\beta}$ \\
\hline \multicolumn{3}{|l|}{ LIFESTYLE CHANGES } \\
\hline Smoking cessation & $\begin{array}{l}\text { Reduction of follicular acanthosis; less xenobiotic metabolism, e.g., via the aryl } \\
\text { hydrocarbon receptor, with potential restoration of alterations in the immune response }\end{array}$ & $(8,49)$ \\
\hline Weight loss & $\begin{array}{l}\text { Improvement of the metabolic state, thereby reducing follicular acanthosis; less } \\
\text { mechanical friction as a result of less overlapping skin folds with potential restoration } \\
\text { of the local microbiome }\end{array}$ & (79) \\
\hline \multicolumn{3}{|l|}{ LOCALLY ADMINISTERED AGENTS } \\
\hline Clindamycin $1 \%$ lotion & Anti-inflammatory and antibacterial properties; for acute lesions & $(80)$ \\
\hline Resorcinol $15 \%$ cream & $\begin{array}{l}\text { Removal of follicular plugging (prophylactic effect) and early rupture of an abscess } \\
\text { due to its keratolytic properties; antiseptic properties }\end{array}$ & $(81,82)$ \\
\hline Intralesional triamcinolone & Pan-cell inhibitor; for acute lesions to eradicate the inflammatory cell infiltrate & (83) \\
\hline \multicolumn{3}{|l|}{ SYSTEMIC ANTIBIOTICS } \\
\hline $\begin{array}{l}\text { Tetracyclins; clindamycin and rifampicin; } \\
\text { moxifloxacin, rifampicin, and metronidazole }\end{array}$ & $\begin{array}{l}\text { Various modulations in the immune response, e.g., inhibition of neutrophilic migration } \\
\text { and chemotaxis, inhibiting IL-1B and TNF- } \alpha \text { secretion, upregulation of IL-10, inhibition } \\
\text { of the angiogenesis, and suppressing T-cell function; antibacterial effects }\end{array}$ & $(80,84-88)$ \\
\hline \multicolumn{3}{|l|}{ BIOLOGICS } \\
\hline $\begin{array}{l}\text { Adalimumab, infliximab; ustekinumab; } \\
\text { anakinra; MABp1 }\end{array}$ & Monoclonal antibodies targeting TNF- $\alpha, \mathrm{IL}-12 / 23 p 40, \mathrm{IL}-1 \mathrm{R}$, and IL-1 $\alpha$, respectively & $(14,89-92)$ \\
\hline \multicolumn{3}{|l|}{ SMALL MOLECULE DRUGS } \\
\hline Apremilast & $\begin{array}{l}\text { Inhibits PDE-4 in various inflammatory cell types, thereby modulating several pro- and } \\
\text { anti-inflammatory cytokines }\end{array}$ & $(93,94)$ \\
\hline \multicolumn{3}{|l|}{ SURGERY } \\
\hline Deroofing, excision & $\begin{array}{l}\text { Removal of irreversibly damaged skin, i.e., sinus tracts or nodules/cysts recurring on } \\
\text { fixed locations }\end{array}$ & $(95,96)$ \\
\hline
\end{tabular}


cessation and weight loss. First-line treatment options include the use of antibiotics with anti-inflammatory properties, e.g., the tetracyclins and the combination of clindamycin and rifampicin $(80,87)$. The anti-TNF- $\alpha$ agents adalimumab and infliximab should be considered, respectively, as first- and second-choice biologics for moderate-to-severe HS after failure of systemic antibiotics $(14,90)$. Ustekinumab (anti-IL-12/23p40) is potentially effective in the treatment of HS (89), whereas the results of two randomized controlled trials investigating IL-17 antagonists are awaited (ClinicalTrials.gov Identifiers NCT02421172 and NCT03248531). Other promising treatment options are MABp1, targeting IL- $1 \alpha$ for HS patients not eligible for adalimumab, and apremilast for patients with moderate HS $(92,94)$.

\section{LIMITATIONS}

This review was subject to certain limitations. PubMed/Medline and EMBASE were the only two databases used to identify eligible studies. Any studies published in journals not listed in PubMed/Medline and EMBASE are omitted from this review. The extent of recent published evidence relating to the pathogenesis of HS and related syndromic conditions is limited. Finally, the review of other IMIDs for comparison with HS was not systematic, and conclusions drawn from this informal review must be interpreted with this methodology in mind.

\section{FUTURE RESEARCH}

Large gaps still remain in the understanding of the pathogenesis of HS. Therefore, further research is warranted to ultimately improve the management and treatment of patients with this disease. Genetic research should aim to add more detail to the proposed mechanism by which loss of function of NCSTN or of other $\gamma$-secretase proteins causes familial HS and to better stratify patients with HS. Immunologic studies should focus

\section{REFERENCES}

1. Zouboulis CC, Desai N, Emtestam L, Hunger RE, Ioannides D, Juhasz $\mathrm{I}$, et al. European S1 guideline for the treatment of hidradenitis suppurativa/acne inversa. J Eur Acad Dermatol Venereol. (2015) 29:619-44. doi: $10.1111 / \mathrm{jdv} .12966$

2. Jemec GB. Quality of life considerations and pain management in hidradenitis suppurativa. Semin Cutan Med Surg. (2017) 36:75-8. doi: 10.12788/j.sder.2017.016

3. Dany M, Elston D. Gene expression of sphingolipid metabolism pathways is altered in hidradenitis suppurativa. J Am Acad Dermatol. (2017) 77:268273.e266. doi: 10.1016/j.jaad.2017.03.016

4. Saunte DML, Jemec GBE. Hidradenitis suppurativa: advances in diagnosis and treatment. JAMA (2017) 318:2019-32. doi: 10.1001/jama.2017.16691

5. Banerjee A, Mcnish S, Shanmugam VK. Interferon-gamma (IFN-gamma) is elevated in wound exudate from hidradenitis suppurativa. Immunol Invest. (2017) 46:149-58. doi: 10.1080/08820139.2016.1230867

6. Von Laffert M, Helmbold P, Wohlrab J, Fiedler E, Stadie V, Marsch WC. Hidradenitis suppurativa (acne inversa): early inflammatory events at terminal follicles and at interfollicular epidermis. Exp Dermatol. (2010) 19:533-7. doi: 10.1111/j.1600-0625.2009.00915.x on molecular drivers of tissue inflammation and injury in HS and the relationship between HS cytokine profile and disease activity. Microbiome research is needed to better characterize the disruption to the microbial ecosystem and to elucidate whether the disruption causes the disease or whether the disease causes the dysbiosis. High-throughput metagenomic methods can make this work possible. Finally, it will be important to focus research on the interaction of environmental factors and immunogenetic factors.

\section{AUTHOR CONTRIBUTIONS}

All authors contributed equally to the design of the literature search, the analysis of results and development of the paper.

\section{FUNDING}

No payments were made to the authors for the development of this manuscript. During preparation of this manuscript, systematic literature search support was provided to the authors by Accuscript; drafts and editorial assistance were provided by Lucid Group. This support was provided by AbbVie Inc. in compliance with international guidelines for good publication practice. The authors maintained complete control over the manuscript content and it reflects their opinions. AbbVie reviewed the final manuscript draft for scientific accuracy, but was not involved in methodology, data collection and analysis, or drafting. AbbVie will pay for page processing charges, if the manuscript is accepted.

\section{SUPPLEMENTARY MATERIAL}

The Supplementary Material for this article can be found online at: https://www.frontiersin.org/articles/10.3389/fimmu. 2018.02965/full\#supplementary-material

7. Von Laffert M, Stadie V, Wohlrab J, Marsch WC. Hidradenitis suppurativa/acne inversa: bilocated epithelial hyperplasia with very different sequelae. $B r \quad J$ Dermatol. (2011) 164:367-71. doi: $10.1111 /$ j.1365-2133.2010.10034.x

8. Sartorius K, Emtestam L, Jemec GB, Lapins J. Objective scoring of hidradenitis suppurativa reflecting the role of tobacco smoking and obesity. Br J Dermatol. (2009) 161:831-9. doi: 10.1111/j.1365-2133.2009. 09198.x

9. Deckers IE, Benhadou F, Koldijk MJ, Del Marmol V, Horvath B, Boer J, et al. Inflammatory bowel disease is associated with hidradenitis suppurativa: results from a multicenter cross-sectional study. J Am Acad Dermatol. (2017) 76:49-53. doi: 10.1016/j.jaad.2016.08.031

10. Van Der Zee HH, De Ruiter L, Van Den Broecke DG, Dik WA, Laman JD, Prens EP. Elevated levels of tumour necrosis factor (TNF)- $\alpha$, interleukin (IL)-1 $\beta$ and IL-10 in hidradenitis suppurativa skin: a rationale for targeting TNF- $\alpha$ and IL-1 $\beta$. Brit J Dermatol. (2011) 164:1292-8. doi: 10.1111/j.1365-2133.2011.10254.x

11. Kelly G, Hughes R, Mcgarry T, Van Den Born M, Adamzik K, Fitzgerald $\mathrm{R}$, et al. Dysregulated cytokine expression in lesional and nonlesional skin in hidradenitis suppurativa. Br J Dermatol. (2015) 173:1431-9. doi: $10.1111 /$ bjd.14075 
12. Moran B, Sweeney CM, Hughes R, Malara A, Kirthi S, Tobin AM, et al. Hidradenitis suppurativa is characterized by dysregulation of the Th17:Treg cell axis, which is corrected by anti-TNF therapy. J Invest Dermatol. (2017) 137:2389-95. doi: 10.1016/j.jid.2017.05.033

13. Emelianov VU, Bechara FG, Glaser R, Langan EA, Taungjaruwinai WM, Schroder JM, et al. Immunohistological pointers to a possible role for excessive cathelicidin (LL-37) expression by apocrine sweat glands in the pathogenesis of hidradenitis suppurativa/acne inversa. Br J Dermatol. (2012) 166:1023-34. doi: 10.1111/j.1365-2133.2011.10765.x

14. Grant A, Gonzalez T, Montgomery MO, Cardenas V, Kerdel FA. Infliximab therapy for patients with moderate to severe hidradenitis suppurativa: a randomized, double-blind, placebo-controlled crossover trial. J Am Acad Dermatol. (2010) 62:205-17. doi: 10.1016/j.jaad.2009.06.050

15. Van Der Zee HH, Laman JD, De Ruiter L, Dik WA, Prens EP. Adalimumab (antitumour necrosis factor-alpha) treatment of hidradenitis suppurativa ameliorates skin inflammation: an in situ and ex vivo study. $\mathrm{Br} J$ Dermatol. (2012) 166:298-305. doi: 10.1111/j.1365-2133.2011.10698.x

16. Wang, B., Yang, W., Wen, W., Sun, J., Su, B., Liu, B., et al. (2010). Gamma-secretase gene mutations in familial acne inversa. Science 330:1065. doi: 10.1126/science.1196284

17. Pan Y, Lin MH, Tian X, Cheng HT, Gridley T, Shen J, et al. gamma-secretase functions through Notch signaling to maintain skin appendages but is not required for their patterning or initial morphogenesis. Dev Cell (2004) 7:73143. doi: 10.1016/j.devcel.2004.09.014

18. Moher, D., Liberati, A., Tetzlaff, J., Altman, D. G., and Group, P. (2009). Preferred reporting items for systematic reviews and metaanalyses: the PRISMA statement. Ann Intern Med. 151, 264-269, W264. doi: 10.7326/0003-4819-151-4-200908180-00135

19. Calderon-Castrat X, Bancalari-Diaz D, Roman-Curto C, Romo-Melgar A, Amoros-Cerdan D, Alcaraz-Mas LA, et al. PSTPIP1 gene mutation in a pyoderma gangrenosum, acne and suppurative hidradenitis (PASH) syndrome. Br J Dermatol. (2016) 175:194-8. doi: 10.1111/bjd.14383

20. Xu H, He Y, Hui Y, Xiao X, Zhang X, Li C, et al. NCSTN mutations in hidradenitis suppurativa/acne inversa do not influence cytokine production by peripheral blood mononuclear cells. Br J Dermatol. (2017) 176:277-9. doi: $10.1111 /$ bjd.15076

21. Vossen AR, Van Der Zee HH, Onderdijk AJ, Boer J, Prens EP. Hidradenitis suppurativa is not associated with the metabolic syndrome based on body type: a cross-sectional study. J Dermatol. (2017) 44:154-9. doi: 10.1111/1346-8138.13572

22. Geusau A, Mothes-Luksch N, Nahavandi H, Pickl WF, Wise CA, Pourpak Z, et al. Identification of a homozygous PSTPIP1 mutation in a patient with a PAPA-like syndrome responding to canakinumab treatment. JAMA Dermatol (2013) 149:209-15. doi: 10.1001/2013.jamadermatol.717

23. Giatrakos S, Huse K, Kanni T, Tzanetakou V, Kramer M, Grech I, et al. Haplotypes of IL-12Rbetal impact on the clinical phenotype of hidradenitis suppurativa. Cytokine (2013) 62:297-301. doi: 10.1016/j.cyto.2013.03.008

24. Marzano AV, Trevisan V, Gattorno M, Ceccherini I, De Simone C, Crosti C. Pyogenic arthritis, pyoderma gangrenosum, acne, and hidradenitis suppurativa (PAPASH): a new autoinflammatory syndrome associated with a novel mutation of the PSTPIP1 gene. JAMA Dermatol. (2013) 149:762-4. doi: 10.1001/jamadermatol.2013.2907

25. Nomura Y, Nomura T, Sakai K, Sasaki K, Ohguchi Y, Mizuno O, et al. A novel splice site mutation in NCSTN underlies a Japanese family with hidradenitis suppurativa. Br J Dermatol. (2013) 168:206-9. doi: 10.1111/j.1365-2133.2012.11174.x

26. Zhang C, Wang L, Chen L, Ren W, Mei A, Chen X, et al. Two novel mutations of the NCSTN gene in Chinese familial acne inverse. J Eur Acad Dermatol Venereol. (2013) 27:1571-4. doi: 10.1111/j.1468-3083.2012.04627.x

27. Marcos T, Ruiz-Martin V, De La Puerta ML, Trinidad AG, Rodriguez Mdel C, De La Fuente MA, et al. Proline-serine-threonine phosphatase interacting protein 1 inhibition of T-cell receptor signaling depends on its $\mathrm{SH} 3$ domain. FEBS J. (2014) 281:3844-54. doi: 10.1111/febs.12912

28. Starnes TW, Bennin DA, Bing X, Eickhoff JC, Grahf DC, Bellak JM, et al. The F-BAR protein PSTPIP1 controls extracellular matrix degradation and filopodia formation in macrophages. Blood (2014) 123:2703-14. doi: 10.1182/blood-2013-07-516948
29. Zeeli T, Padalon-Brauch G, Ellenbogen E, Gat A, Sarig O, Sprecher E. Pyoderma gangrenosum, acne and ulcerative colitis in a patient with a novel mutation in the PSTPIP1 gene. Clin Exp Dermatol. (2015) 40:367-72. doi: $10.1111 /$ ced. 12585

30. Giamarellos-Bourboulis, E. J., Platzer, M., Karagiannidis, I., Kanni, T., Nikolakis, G., Ulrich, J., et al. (2016). High copy numbers of beta-defensin cluster on 8p23.1, confer genetic susceptibility, and modulate the physical course of hidradenitis suppurativa/acne inversa. J Invest Dermatol. 136, 1592 1598. doi: 10.1016/j.jid.2016.04.021

31. Xiao X, He Y, Li C, Zhang X, Xu H, Wang B. Nicastrin mutations in familial acne inversa impact keratinocyte proliferation and differentiation through the Notch and phosphoinositide 3-kinase/AKT signalling pathways. $\mathrm{Br} \mathrm{J}$ Dermatol. (2016) 174:522-32. doi: 10.1111/bjd.14223

32. Li N, Ma J, Li K, Guo C, Ming L. Different contributions of CDKAL1, KIF21B, and LRRK2/MUC19 polymorphisms to SAPHO syndrome, rheumatoid arthritis, ankylosing spondylitis, and seronegative spondyloarthropathy. Genet Test Mol Biomarkers (2017) 21:122-6. doi: 10.1089/gtmb.2016.0112

33. Marzano AV, Damiani G, Ceccherini I, Berti E, Gattorno M, Cugno M. Autoinflammation in pyoderma gangrenosum and its syndromic form (pyoderma gangrenosum, acne and suppurative hidradenitis). $\mathrm{Br}$ J Dermatol. (2017) 176:1588-98. doi: 10.1111/bjd.15226

34. Wolk K, Wenzel J, Tsaousi A, Witte-Handel E, Babel N, Zelenak C, et al. Lipocalin-2 is expressed by activated granulocytes and keratinocytes in affected skin and reflects disease activity in acne inversa/hidradenitis suppurativa. Br J Dermatol. (2017) 177:1385-1393. doi: 10.1111/bjd.15424

35. Mozeika E, Pilmane M, Nurnberg BM, Jemec GB. Tumour necrosis factor-alpha and matrix metalloproteinase-2 are expressed strongly in hidradenitis suppurativa. Acta Derm Venereol. (2013) 93:301-4. doi: 10.2340/00015555-1492

36. Hessam S, Sand M, Gambichler T, Bechara FG. Correlation of inflammatory serum markers with disease severity in patients with hidradenitis suppurativa (HS). J Am Acad Dermatol. (2015) 73:998-1005. doi: 10.1016/j.jaad.2015.08.052

37. Di Caprio R, Balato A, Caiazzo G, Lembo S, Raimondo A, Fabbrocini G, et al. IL-36 cytokines are increased in acne and hidradenitis suppurativa. Arch Dermatol Res. (2017) 309:673-8. doi: 10.1007/s00403-017-1769-5

38. Jimenez-Gallo D, De La Varga-Martinez R, Ossorio-Garcia L, AlbarranPlanelles C, Rodriguez C, Linares-Barrios M. The clinical significance of increased serum proinflammatory cytokines, C-reactive protein, and erythrocyte sedimentation rate in patients with hidradenitis suppurativa. Mediators Inflamm. (2017) 2017:2450401. doi: 10.1155/2017/2450401

39. Matusiak L, Szczech J, Bieniek A, Nowicka-Suszko D, Szepietowski JC. Increased interleukin (IL)-17 serum levels in patients with hidradenitis suppurativa: implications for treatment with anti-IL-17 agents. J Am Acad Dermatol. (2017) 76:670-5. doi: 10.1016/j.jaad.2016.10.042

40. Theut Riis P, Von Stemann JH, Kjaersgaard Andersen R, Hansen MB, Jemec GBE. Serum anticytokine autoantibody levels are not increased in hidradenitis suppurativa: a case-control pilot study. Dermatology (2017) 233:126-8. doi: 10.1159/000475925

41. Thomi R, Kakeda M, Yawalkar N, Schlapbach C, Hunger RE. Increased expression of the interleukin-36 cytokines in lesions of hidradenitis suppurativa. J Eur Acad Dermatol Venereol. (2017) 31:2091-96. doi: $10.1111 /$ jdv.14389

42. Thomi R, Yerly D, Yawalkar N, Simon D, Schlapbach C, Hunger RE. Interleukin-32 is highly expressed in lesions of hidradenitis suppurativa. $\mathrm{Br}$ J Dermatol. (2017) 177:1358-66. doi: 10.1111/bjd.15458

43. Guet-Revillet H, Coignard-Biehler H, Jais JP, Quesne G, Frapy E, Poiree S, et al. Bacterial pathogens associated with hidradenitis suppurativa, France. Emerg Infect Dis. (2014) 20:1990-8. doi: 10.3201/eid2012.140064

44. Hotz C, Boniotto M, Guguin A, Surenaud M, Jean-Louis F, Tisserand $\mathrm{P}$, et al. Intrinsic defect in keratinocyte function leads to inflammation in hidradenitis suppurativa. J Invest Dermatol. (2016) 136:1768-80. doi: 10.1016/j.jid.2016.04.036

45. Guet-Revillet H, Jais JP, Ungeheuer MN, Coignard-Biehler H, Duchatelet S, Delage $\mathrm{M}$, et al. The microbiological landscape of anaerobic infections in hidradenitis suppurativa: a prospective metagenomic study. Clin Infect Dis. (2017) 65:282-91. doi: 10.1093/cid/cix285 
46. Nikolakis G, Liakou AI, Bonovas S, Seltmann H, Bonitsis N, Join-Lambert O, et al. Bacterial colonization in hidradenitis suppurativa/acne inversa: a crosssectional study of 50 patients and review of the literature. Acta Derm Venereol. (2017) 97:493-8. doi: 10.2340/00015555-2591

47. Ring HC, Bay L, Nilsson M, Kallenbach K, Miller IM, Saunte DM, et al. Bacterial biofilm in chronic lesions of hidradenitis suppurativa. $\mathrm{Br} J$ Dermatol. (2017) 176:993-1000. doi: 10.1111/bjd.15007

48. Ring HC, Thorsen J, Saunte DM, Lilje B, Bay L, Riis PT, et al. The follicular skin microbiome in patients with hidradenitis suppurativa and healthy controls. JAMA Dermatol (2017) 153:897-905. doi: 10.1001/jamadermatol.2017.0904

49. Kromann CB, Deckers IE, Esmann S, Boer J, Prens EP, Jemec GB. Risk factors, clinical course and long-term prognosis in hidradenitis suppurativa: a crosssectional study. Br J Dermatol. (2014) 171:819-24. doi: 10.1111/bjd.13090

50. Guillet A, Brocard A, Bach Ngohou K, Graveline N, Leloup AG, Ali D, et al. Verneuil's disease, innate immunity and vitamin D: a pilot study. J Eur Acad Dermatol Venereol. (2015) 29:1347-53. doi: 10.1111/jdv.12857

51. Boer J. Should hidradenitis suppurativa be included in dermatoses showing koebnerization? Is it friction or fiction? Dermatology (2017) 233:47-52. doi: 10.1159/000472252

52. Vossen AR, Van Straalen KR, Prens EP, Van Der Zee HH. Menses and pregnancy affect symptoms in hidradenitis suppurativa: a cross-sectional study. J Am Acad Dermatol. (2017) 76:155-6. doi: 10.1016/j.jaad.2016.07.024

53. Hugot JP, Chamaillard M, Zouali H, Lesage S, Cezard JP, Belaiche J, et al. Association of NOD2 leucine-rich repeat variants with susceptibility to Crohn's disease. Nature (2001) 411:599-603. doi: 10.1038/35079107

54. Ogura Y, Bonen DK, Inohara N, Nicolae DL, Chen FF, Ramos R, et al. A frameshift mutation in NOD2 associated with susceptibility to Crohn's disease. Nature (2001) 411:603-6. doi: 10.1038/35079114

55. Park JH, Peyrin-Biroulet L, Eisenhut M, Shin JI. IBD immunopathogenesis: a comprehensive review of inflammatory molecules. Autoimmun Rev. (2017) 16:416-26. doi: 10.1016/j.autrev.2017.02.013

56. Gooren LJ, Giltay EJ, Van Schaardenburg D, Dijkmans BA. Gonadal and adrenal sex steroids in ankylosing spondylitis. Rheum Dis Clin North Am. (2000) 26:969-87. doi: 10.1016/S0889-857X(05)70179-4

57. Sparks JA, Costenbader KH. Genetics, environment, and gene-environment interactions in the development of systemic rheumatic diseases. Rheum Dis Clin North Am. (2014) 40:637-57. doi: 10.1016/j.rdc.2014.07.005

58. Videm V, Cortes A, Thomas R, Brown MA. Current smoking is associated with incident ankylosing spondylitis - the HUNT population-based Norwegian health study. J Rheumatol. (2014) 41:2041-8. doi: 10.3899/jrheum.140353

59. Jethwa H, Bowness P. The interleukin (IL)-23/IL-17 axis in ankylosing spondylitis: new advances and potentials for treatment. Clin Exp Immunol. (2016) 183:30-6. doi: 10.1111/cei.12670

60. O'rielly DD, Uddin M, Rahman P. Ankylosing spondylitis: beyond genome-wide association studies. Curr Opin Rheumatol. (2016) 28:337-45. doi: 10.1097/BOR.0000000000000297

61. Brown MA. Solving the pathogenesis of ankylosing spondylitis. Clin Immunol. (2017) 186:46-50. doi: 10.1016/j.clim.2017.07.011

62. Li Z, Brown MA. Progress of genome-wide association studies of ankylosing spondylitis. Clin Transl Immunol. (2017) 6:e163. doi: 10.1038/cti.2017.49

63. Ho P, Bruce IN, Silman A, Symmons D, Newman B, Young H, et al. Evidence for common genetic control in pathways of inflammation for Crohn's disease and psoriatic arthritis. Arthritis Rheum. (2005) 52:3596-602. doi: 10.1002/art.21393

64. Strange A, Capon F, Spencer CC, Knight J, Weale ME, Allen MH, et al. A genome-wide association study identifies new psoriasis susceptibility loci and an interaction between HLA-C and ERAP1. Nat Genet. (2010) 42:985-90. doi: 10.1038/ng.694

65. Love TJ, Zhu Y, Zhang Y, Wall-Burns L, Ogdie A, Gelfand JM, et al. Obesity and the risk of psoriatic arthritis: a population-based study. Ann Rheum Dis. (2012) 71:1273-7. doi: 10.1136/annrheumdis-2012-201299

66. El-Boghdady NA, Ismail MF, Abd-Alhameed MF, Ahmed AS, Ahmed HH. Bidirectional association between psoriasis and obesity: benefits and risks. $J$ Interferon Cytokine Res. (2017) 38:12-19. doi: 10.1089/jir.2017.0105

67. Ogawa E, Sato Y, Minagawa A, Okuyama R. Pathogenesis of psoriasis and development of treatment. J Dermatol. (2017) 45:264-72. doi: $10.1111 / 1346-8138.14139$
68. Nguyen UDT, Zhang Y, Lu N, Louie-Gao Q, Niu J, Ogdie A, et al. Smoking paradox in the development of psoriatic arthritis among patients with psoriasis: a population-based study. Ann Rheum Dis. (2018) 77:119-23. doi: 10.1136/annrheumdis-2017-211625

69. Thomsen SF, Sorensen LT. Smoking and skin disease. Skin Therapy Lett. (2010) 15:4-7.

70. Al Ghazal P, Korber A, Klode J, Dissemond J. Investigation of new co-factors in 49 patients with pyoderma gangrenosum. J Dtsch Dermatol Ges. (2012) 10:251-7. doi: 10.1111/j.1610-0387.2011.07734.x

71. Shavit E, Alavi A, Sibbald RG. Pyoderma gangrenosum: a critical appraisal. Adv Skin Wound Care (2017) 30:534-42. doi: 10.1097/01.ASW.0000526605.34372.9e

72. Hemminki K, Li X, Sundquist J, Sundquist K. Risk of asthma and autoimmune diseases and related conditions in patients hospitalized for obesity. Ann Med. (2012) 44:289-95. doi: 10.3109/07853890.2010.547515

73. Lopalco G, Lucherini OM, Lopalco A, Venerito V, Fabiani C, Frediani B, et al. Cytokine signatures in mucocutaneous and ocular Behcet's disease. Front Immunol. (2017) 8:200. doi: 10.3389/fimmu.2017.00200

74. Scherrer MAR, Rocha VB, Garcia LC. Behcet's disease: review with emphasis on dermatological aspects. An Bras Dermatol. (2017) 92:452-64. doi: 10.1590/abd1806-4841.20177359

75. Zhu K, Yin X, Tang X, Zhang F, Yang S, Zhang X. Meta-analysis of NOD2/CARD15 polymorphisms with psoriasis and psoriatic arthritis. Rheumatol Int. (2012) 32:1893-900. doi: 10.1007/s00296-011-1813-2

76. Hodak E, Atzmony L, Pavlovsky L, Comaneshter D, Cohen AD. Hidradenitis suppurativa is associated with familial mediterranean fever-a population-based study. J Invest Dermatol. (2017) 137:2019-21. doi: 10.1016/j.jid.2017.04.024

77. Dessinioti C, Katsambas A, Antoniou C. Hidradenitis suppurrativa (acne inversa) as a systemic disease. Clin Dermatol. (2014) 32:397-408. doi: 10.1016/j.clindermatol.2013.11.006

78. Van Straalen KR, Schneider-Burrus S, Prens EP. Current and future treatment of hidradenitis suppurativa. Br J Dermatol. (2018). doi: 10.1111/bjd.16768. [Epub ahead of print].

79. Kromann CB, Ibler KS, Kristiansen VB, Jemec GB. The influence of body weight on the prevalence and severity of hidradenitis suppurativa. Acta Derm Venereol. (2014) 94:553-7. doi: 10.2340/00015555-1800

80. Jemec GB, Wendelboe P. Topical clindamycin versus systemic tetracycline in the treatment of hidradenitis suppurativa. J Am Acad Dermatol. (1998) 39:971-4. doi: 10.1016/S0190-9622(98)70272-5

81. Boer J, Jemec GB. Resorcinol peels as a possible self-treatment of painful nodules in hidradenitis suppurativa. Clin Exp Dermatol. (2010) 35:36-40. doi: 10.1111/j.1365-2230.2009.03377.x

82. Pascual JC, Encabo B, Ruiz De Apodaca RF, Romero D, Selva J, Jemec GB. Topical 15\% resorcinol for hidradenitis suppurativa: an uncontrolled prospective trial with clinical and ultrasonographic follow-up. J Am Acad Dermatol. (2017) 77:1175-8. doi: 10.1016/j.jaad.2017.07.008

83. Riis PT, Boer J, Prens EP, Saunte DM, Deckers IE, Emtestam L, et al. Intralesional triamcinolone for flares of hidradenitis suppurativa (HS): a case series. J Am Acad Dermatol. (2016) 75:1151-5. doi: 10.1016/j.jaad.2016.06.049

84. Ziglam HM, Daniels I, Finch RG. Immunomodulating activity of rifampicin. J Chemother. (2004) 16:357-61. doi: 10.1179/joc.2004.16.4.357

85. Pasquale TR, Tan JS. Nonantimicrobial effects of antibacterial agents. Clin Infect Dis. (2005) 40:127-35. doi: 10.1086/426545

86. Sapadin AN, Fleischmajer R. Tetracyclines: nonantibiotic properties and their clinical implications. J Am Acad Dermatol. (2006) 54:258-65. doi: 10.1016/j.jaad.2005.10.004

87. Gener G, Canoui-Poitrine F, Revuz JE, Faye O, Poli F, Gabison G, et al. Combination therapy with clindamycin and rifampicin for hidradenitis suppurativa: a series of 116 consecutive patients. Dermatology (2009) 219:14854. doi: 10.1159/000228334

88. Join-Lambert O, Coignard H, Jais JP, Guet-Revillet H, Poiree S, Fraitag $\mathrm{S}$, et al. Efficacy of rifampin-moxifloxacin-metronidazole combination therapy in hidradenitis suppurativa. Dermatology (2011) 222:49-58. doi: $10.1159 / 000321716$

89. Blok JL, Li K, Brodmerkel C, Horvatovich P, Jonkman MF, Horvath B. Ustekinumab in hidradenitis suppurativa: clinical results and a search 
for potential biomarkers in serum. Br J Dermatol. (2016) 174:839-46. doi: 10.1111/bjd.14338

90. Kimball AB, Okun MM, Williams DA, Gottlieb AB, Papp KA, Zouboulis CC, et al. Two phase 3 trials of adalimumab for hidradenitis suppurativa. $N$ Engl $J$ Med. (2016) 375:422-34. doi: 10.1056/NEJMoa1504370

91. Tzanetakou V, Kanni T, Giatrakou S, Katoulis A, Papadavid E, Netea MG, et al. Safety and efficacy of anakinra in severe hidradenitis suppurativa: a randomized clinical trial. JAMA Dermatol. (2016) 152:52-9. doi: 10.1001/jamadermatol.2015.3903

92. Kanni T, Argyropoulou M, Spyridopoulos T, Pistiki A, Stecher M, Dinarello $\mathrm{CA}$, et al. MABp1 targeting IL-1alpha for moderate to severe hidradenitis suppurativa not eligible for adalimumab: a randomized study. $J$ Invest Dermatol. (2018) 138:795-801. doi: 10.1016/j.jid.2017.10.030

93. Schafer PH, Parton A, Gandhi AK, Capone L, Adams M, Wu L, et al. Apremilast, a cAMP phosphodiesterase-4 inhibitor, demonstrates antiinflammatory activity in vitro and in a model of psoriasis. Br J Pharmacol. (2010) 159:842-55. doi: 10.1111/j.1476-5381.2009.00559.x

94. Vossen ARJ, Van Doorn MBA, Van Der Zee HH, Prens EP. Apremilast for moderate hidradenitis suppurativa: results of a randomized controlled trial. J Am Acad Dermatol. (2018). doi: 10.1016/j.jaad.2018.06.046. [Epub ahead of print].

95. Van Der Zee HH, Prens EP, Boer J. Deroofing: a tissue-saving surgical technique for the treatment of mild to moderate hidradenitis suppurativa lesions. J Am Acad Dermatol. (2010) 63:475-80. doi: 10.1016/j.jaad.2009.12.018

96. Mehdizadeh A, Hazen PG, Bechara FG, Zwingerman N, Moazenzadeh M, Bashash M, et al. Recurrence of hidradenitis suppurativa after surgical management: a systematic review and meta-analysis. J Am Acad Dermatol. (2015) 73:S70-77. doi: 10.1016/j.jaad.2015.07.044

Conflict of Interest Statement: HvdZ: advisory board member for AbbVie, InflaRX, and Galderma. EP: consultant, speaker, principal investigator or received grants from: AbbVie, Amgen, Biogen, Celgene, Eli Lilly, Janssen-Cilag, Novartis, Pfizer, and UCB.

The remaining author declares that the research was conducted in the absence of any commercial or financial relationships that could be construed as a potential conflict of interest.

Copyright (c) 2018 Vossen, van der Zee and Prens. This is an open-access article distributed under the terms of the Creative Commons Attribution License (CC BY). The use, distribution or reproduction in other forums is permitted, provided the original author(s) and the copyright owner(s) are credited and that the original publication in this journal is cited, in accordance with accepted academic practice. No use, distribution or reproduction is permitted which does not comply with these terms. 